\title{
Dynamics and Seasonality of the Leeuwin Current and the Surrounding Counter-Current System in the Region South of Western Australia
}

\author{
Mohd Fadzil Akhir ${ }^{1, *(\mathbb{D})}$, Charitha Pattiaratchi ${ }^{2}$ and Michael Meuleners ${ }^{2}$ \\ 1 Institute of Oceanography and Environment, Universiti Malaysia Terengganu, Kuala Nerus 21030, Malaysia \\ 2 Ocean Graduate School, University of Western Australia, Crawley WA 6009, Australia; \\ chari.pattiaratchi@uwa.edu.au (C.P.);m.meuleners@uwa.edu.au (M.M.) \\ * Correspondence: mfadzil@umt.edu.my
}

Received: 6 May 2020; Accepted: 20 July 2020; Published: 23 July 2020

\begin{abstract}
Surface circulation associated with the Leeuwin Current System off the southern coast of Western Australia was simulated using the Regional Ocean Model Systems (ROMS). The Leeuwin current (LC) and Flinders current (FC) were reproduced in two simulation: with and without wind stress. The inclusion of wind resulted in a strong LC during autumn and winter months with the LC flowing close to the shelf, accelerating after reaching the south-west corner at Cape Leeuwin. The geopotential gradient was present through all seasons, indicating that it is the major driving force of the currents. At the subsurface, continuation of the opposing undercurrent present at the southwest corner. Interchanging of strength and transport between LC and FC can be seen between seasons, where LC strength drops significantly in autumn and winter when the wind stress is low and this subsequently increases the FC transport. The FC strength declines in summer when there is no wind stress, which during this time LC is stronger. Meanwhile, the analysis shows an inshore presence of Cresswell current is evident along the coast when there is south-easterly wind in summer. The study provides comprehensive overview of the complex currents system where wind influence proves to be determining factors to the current system.
\end{abstract}

Keywords: Leeuwin current; Flinders current; Cresswell current; seasonal changes; geopotential gradient; southwest of Australia

\section{Introduction}

The unique current system off Western Australia's south coast consists of three main current systems, defined as the Leeuwin Current System, that comprise of [1-5]: (1) the eastward flowing Leeuwin current at the shelf break and slope; (2) the westward flowing Flinders current, flowing offshore and beneath the Leeuwin current; and, (3) the wind-driven, westward flowing Cresswell current on the continental shelf during the summer in response to easterly, upwelling favourable winds.

The Leeuwin current (LC) is a continuous boundary current $[5,6]$ centered along the shelf break ( $\sim 200 \mathrm{~m}$ depth) that flows southward along the west coast of Australia and eastward into the Great Australian Bight (GAB) $[7,8]$. The Flinders current (FC), the only northern boundary current in the Southern Hemisphere $[9,10]$, interacts with the LC on the continental shelf and flows on the outer part of the shelf break. The flow is opposite to the direction of LC. Part of the FC flows beneath the LC and feeds the Leeuwin undercurrent (LU), flowing northwards along the west coast $[1-3,5]$. The LC undergoes an 'ageing' process along Western Australia's west coast [10]. Here, water from the central Indian ocean is advected onto the LC, changing its water mass characteristics as it flows southward [2,11]. The region off the southern coast of Western Australia, the study area of this paper, 
is where the Leeuwin current is the strongest [12] due to inflow from the South Indian Counter Current (SICC) into the LC at around $32^{\circ} \mathrm{S}[5,13]$ and an enhanced alongshore geopotential gradient [14].

An alongshore geopotential gradient drives the LC along the west and south coasts, but an enhanced gradient at the southwest corner accelerate the LC locally. Akhir [4] reported field measurements that supported the concept that the LC accelerated at the south west corner during autumn. There is a $90^{\circ}$ change in the shoreline orientation at Cape Leeuwin (Figure 1a) and due to the Coriolis force, the LC also follows this change. Higher LC speeds and changes in the main current direction generate eddies between $115^{\circ}$ and $117^{\circ} \mathrm{E}$, as a result of barotropic and baroclinic instabilities [14,15]. The LC also meanders on and off the shelf throughout the year $[7,8]$.
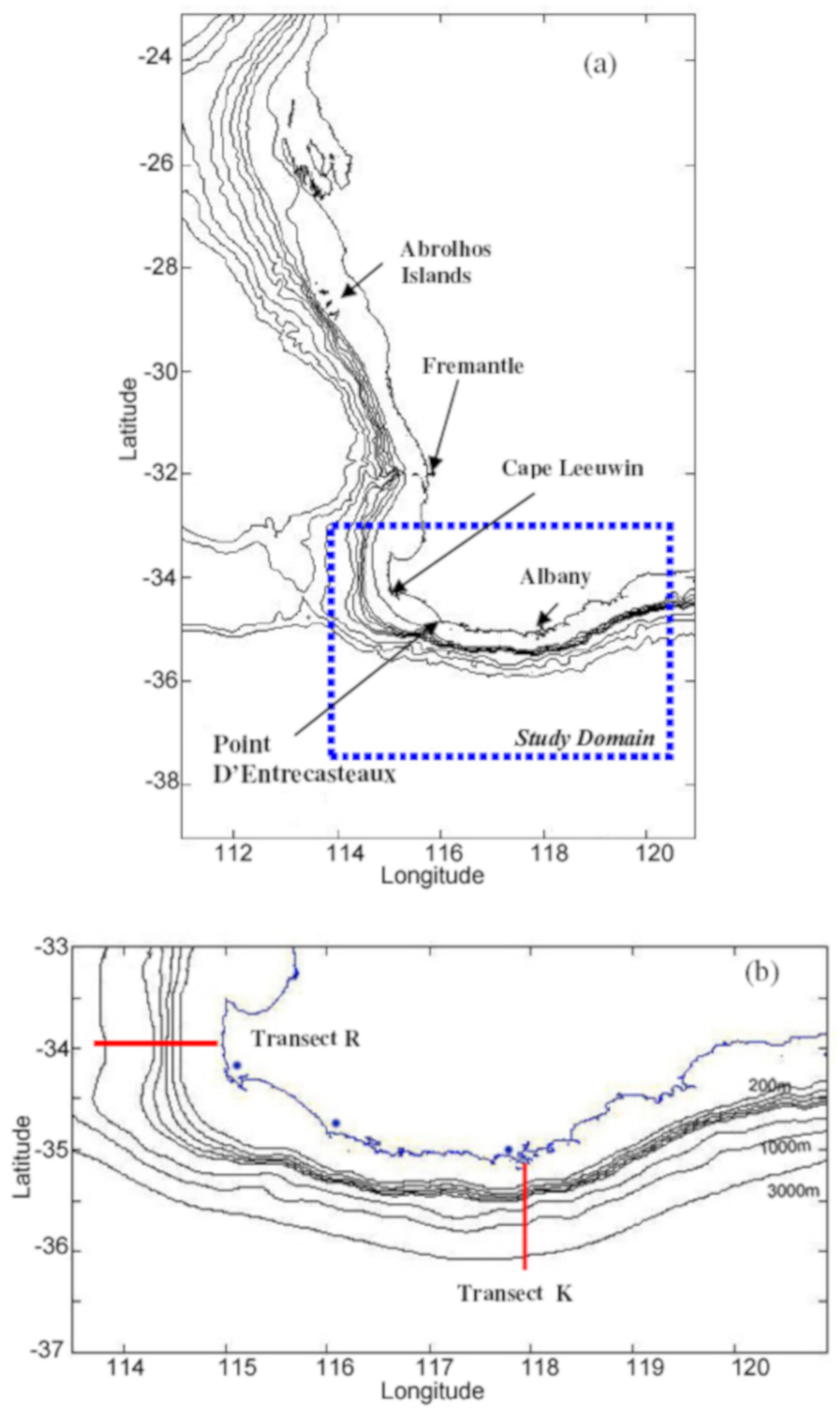

Figure 1. (a) Model domain with bathymetry contour lines with specific name of places that will be referred throughout the paper. (b) The study area overlaid with the field transect of the Southern Surveyor cruise SS04/06. The current system was observed. 
The Flinders current (FC), flows to the west, driven by the large-scale wind stress curl to the south of Australia $[9,10]$. Observations related to these subsurface currents are limited, nevertheless recent studies using field measurements [4] and numerical modelling [5] have demonstrated a better representation of the current. The FC is both a surface current as well as an undercurrent $[5,10]$. Here, the FC flows to the west, in the opposite directions to the LC, with the main current flow located offshore of the LC. FC flows also flows beneath the LC, in a similar manner to the LU along the west coast [1,2], and mainly consists of sub-Antarctic mode water (SAMW), with the 'core' of the current located at a depth of $400 \mathrm{~m}$ [1].

During the summer months, wind-driven currents are present on the continental shelf that flow opposite to the LC $[16,17]$. The seasonal presence of these coastal current along the study area was first observed by [16]. This coastal current, which is known as Capes Current, is a cooler continental shelf current, driven by a southerly wind stress, which overcomes the alongshore geopotential gradient, mainly during the summer months [17]. The cooler signature of the current is due to wind-driven upwelling. Capes current originates from the region between Capes Leeuwin and Naturaliste and moves equatorward $[16,17]$. Along the south coast, patches of colder water were observed in the Recherché Archipelago and adjacent waters [7]. It has been postulated that a wind-driven coastal current, similar to the CC, defined as the Cresswell current, moves westward in response to the strong southeasterly summer winds, which are the major driving forces of the current and upwelling [18]. It is similar to the Capes current that flows along the south coast from east to west in response to easterly wind stress during the summer, and has only been postulated and observed in satellite imagery. The dynamics of the current remain largely unknown, but are thought to be similar to that of the Capes current [16,17].

The summary indicated that the study region is one of least studied regions in Australian water in terms of physical oceanography. In particular, the dynamics and forcing mechanisms of the major currents and their interaction is relatively unknown. In this study, we use numerical model simulations to examine the dynamics of the circulation along the south-west coast of Western Australia, especially focusing at Leeuwin current (LC) and how it interacts with the counter currents system that flows in the opposite direction. The main aims of the paper are: (1) determine the major driving force of the Leeuwin current and whether wind stress during winter enhances the transport; (2) define the interaction and connectivity between the LC, Flinders current and the Leeuwin undercurrent; and, (3) confirm the presence of a wind driven continental shelf current, the Cresswell current, during the summer months.

\section{Materials and Methods}

The three-dimensional model used was the Regional Ocean Modelling System (ROMS) v. 2.1 [19,20]. ROMS is a hydrostatic, primitive equation ocean model, which solves the Reynolds-averaged form of the Navier-Stokes equations on an Arakawa C grid, and uses stretched, terrain-following (sigma) coordinates in the vertical. Here, the model's horizontal advection scheme was configured using a third-order, upstream-bias G-Scheme [21] and a spline advection scheme for the vertical transport. The baroclinic hydrostatic pressure gradient term was examined using Song and Wright's [22] weighted Jacobian pressure gradient scheme. The parameterization of vertical turbulent mixing for momentum and tracers was based on the Mellor-Yamada 2.5-order closure model [23]. The horizontal eddy coefficient, used for momentum and tracers, adopted a Laplacian parameterization. More details on the model configuration is presented in Meuleners et al. [24].

The model domain encompassed Western Australia's west and south coasts ( $\left.26-38^{\circ} \mathrm{S}, 109-126^{\circ} \mathrm{W}\right)$ (Figure 1a). It consisted of three open boundaries at the study region's northern, southern, and western extents. A time-varying boundary condition for temperature and salinity was maintained at all the open boundaries to represent the external forcing. Radiation boundary conditions were prescribed for the baroclinic tracers. The forcing data were sourced from the Bluelink Ocean Data Assimilation System (BODAS), which has a resolution of $10 \times 10 \mathrm{~km}$ and was designed to forecast and reanalyze the 
oceans around Australia [25]. The daily data of Bluelink from year 2003 and 2004 was used to complete the model runs. This configuration of boundary forcing has been successfully undertaken in previous numerical modelling studies in the region using ROMS [5,24].

A minimum of a one-year simulation was required to assess the seasonal variability in the study region. Therefore, the model was run for 600 days to cover a simulation of a complete year to reach quasi-equilibrium state (spin-up) after $\sim 250$ days. The horizontal resolution was set to a $\sim 2.5 \mathrm{~km}$ in the east/west and north/south directions. The bathymetric data were sourced from Geoscience Australia at a resolution of $1 \mathrm{~km}$. The model domain's minimum depth was set to $20 \mathrm{~m}$ and the number of vertical sigma layers was 25 , with increased resolution in the near surface. A quadratic bottom-drag coefficient was used to compute the bottom stress, and the model was set to perform two runs, with and without wind stress forcing. The selection of the model vertical and horizontal resolution tries to satisfy the objectives of the study, which is to resolve current system at both areas on the shelf and at the shelf slope.

The wind stress forcing was extracted from wind data obtained from the NCEP/NCAR Reanalysis data from National Oceanic and Atmospheric Administration (NOAA). The data was obtained for particular year of the model run (2003 and 2004). The data provide daily wind stress with spatial resolution of $1^{\circ}$. This data then was interpolated to incorporate within the model. The spatial and temporal resolution of the wind data is appropriate to provide enough coverage for seasonal variation for the study domain. Often, the Capes region and south of WA is a boundary for wind direction to change direction [12]. This important feature in wind direction changes are well-resolved within the wind data set. Averaged wind stress for both winter and summer clearly distinguish the difference in wind pattern to the system, particularly at Capes and southern WA region.

\section{Results}

In this section, we compare the model output with satellite imagery and discuss the seasonal variability of the Leeuwin Current System along the south coast of WA. Results from the model runs undertaken with and without wind forcing will then be compared to identify the role of wind stress as a driving force of the Leeuwin current along the south coast. Two transects (based on shipborne observations), transects R (Capes region) and K (Albany) (Figure 1b), located along the west and south coast, respectively, were selected to examine the cross-section profile.

A satellite image of the sea surface temperature off south-west Australia on 9 April 2006 (Figure 2a) showed a warm LC near the Capes region, typical of the circulation pattern during autumn. The model output of the sea surface temperature during autumn conditions showed that the model reproduced the broad-scale features of the satellite image (Figure 2b); a band of warmer LC was located near the shelf and span continuously along the shelf break. Along the south coast, the strong temperature front due to the interaction between the warmer LC and the cooler FC was prominent. In the Capes region, an eddy generated off Cape Leeuwin $\left(34.5^{\circ} \mathrm{S}\right)$ was almost identical to the eddy in the satellite image; a patch of cold water drawn from the anti-cyclonic eddy could also be seen. Nevertheless, LC temperature along southern coast was overestimated, mainly because the model did not use data assimilation with no fluxes of heat. 


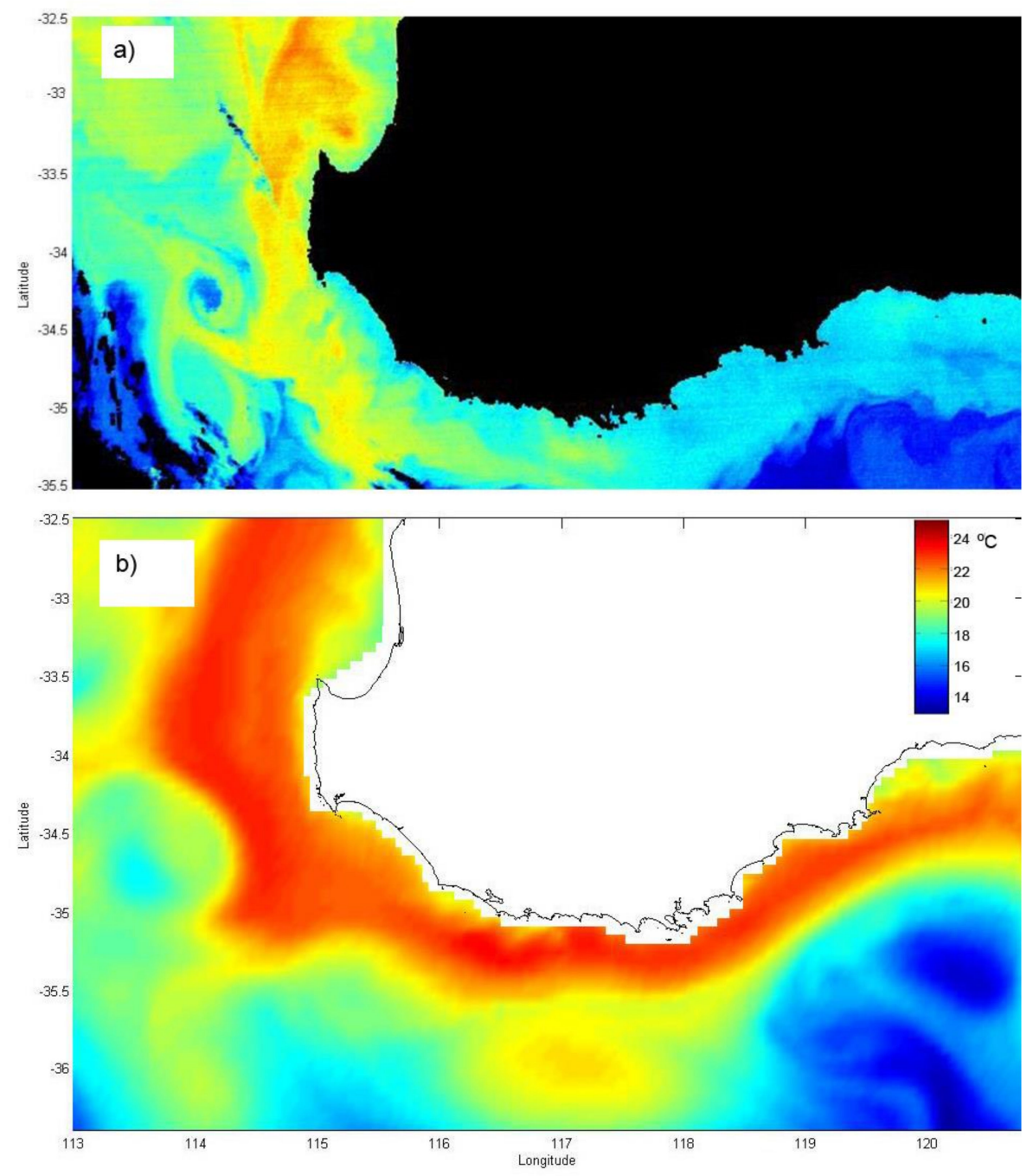

Figure 2. (a) National Oceanic and Atmospheric Administration (NOAA) satellite image of south-west Australia on 9 April 2006. The warm water (shown in red/orange) represents the Leeuwin current. (b) A model output of the surface temperature representing circulation in the autumn and showing an eddy offshoot south.

Shipborne Acoustic Doppler Current Profiler (ADCP RDI 75 kHz) cross-shelf transects, available from April 2006 (i.e., not coincident with the period of numerical simulations), were available for indirect comparison (Figure 3): two of the transects were from the southern coast and one along the west coast (Figure 1). Along the southern coast, both transects show the strong eastward flowing Leeuwin current (warmer colors) with maximum current speeds $>1 \mathrm{~ms}^{-1}$ in the surface $200 \mathrm{~m}$ (Figure $3 \mathrm{~b}, \mathrm{c}$ ). The westward flowing Flinders current (cooler colors) can be identified and show that it is both a surface current further offshore and an undercurrent beneath the Leeuwin current extending to the range to the range of the ADCP $(800 \mathrm{~m})$. Note also that higher current speeds of in the Flinders currents were recorded beneath the Leeuwin current, with speeds $>0.40 \mathrm{~ms}^{-1}$ (Figure $3 b, c$ ). Along the west coast, the Leeuwin current was weaker and extended across the whole transect. The Leeuwin undercurrent is present as a northward flow beneath the Leeuwin current (Figure 3a). 

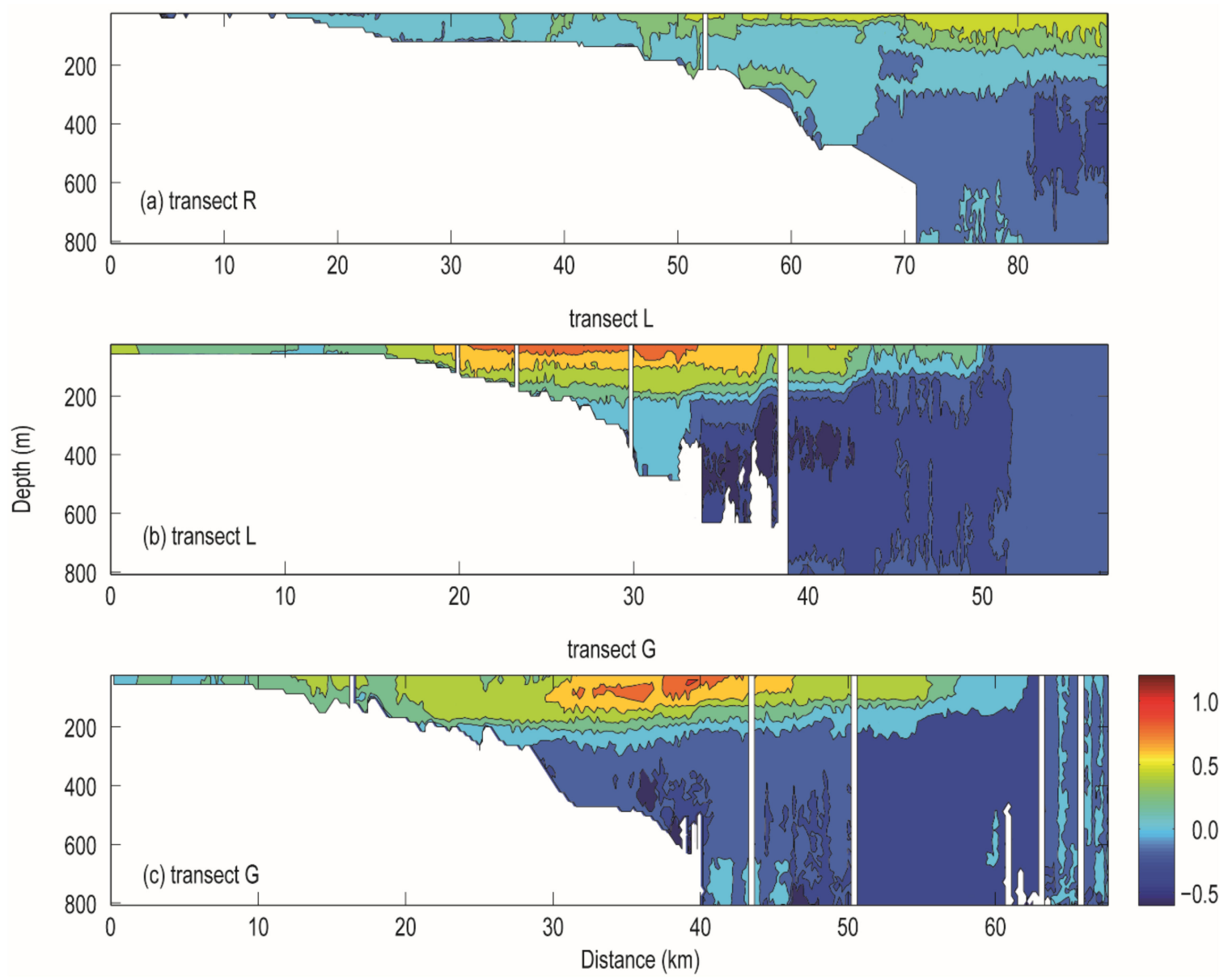

Figure 3. Cross-shelf Acoustic Doppler Current Profiler (ADCP) transects obtained in April 2006 using the RV Southern Surveyor and an RDI $75 \mathrm{kHz}$ ADCP. Locations of transects are shown on Figure 1. Units are $\mathrm{ms}^{-1}$. In (a) positive values (warmer colors) represent southward flow whist in (b) and (c) positive values represent eastward flow.

\subsection{Seasonal Characteristics}

\subsubsection{Summer}

During the summer months, the LC had a maximum speed of $\sim 1.0 \mathrm{~m} / \mathrm{s}$ (Figure $4 \mathrm{a}$ ). It was positioned offshore from the shelf break and advected warm water into the southern region. The presence of coastal currents on the shelf had pushed the LC offshore from the shelf, as described by Pearce and Pattiaratchi [16]. A maximum temperature difference between the shelf waters and the LC of $\sim 5{ }^{\circ} \mathrm{C}$ was predicted by the model. Such a difference is expected during summer because nearshore areas are cooler due to upwelling generated by southerly winds.

Transect $R$ (west coast; Figure 1b) showed a poleward LC with a maximum speed of $\sim 1.0 \mathrm{~m} / \mathrm{s}$, located just offshore of the shelf break, and an equatorward Capes current with a maximum speed of $\sim 0.2 \mathrm{~m} / \mathrm{s}$, inshore of the continental shelf (Figure $4 \mathrm{~b}$ ). The transect also indicated the presence of the equatorward Leeuwin undercurrent beneath the LC flowing adjacent to the continental slope between 400 and $1000 \mathrm{~m}$ depth with speeds of $\sim 0.2 \mathrm{~m} / \mathrm{s}$ centered at $400 \mathrm{~m}$ depth.

The LC maintained its speed as it flowed into the southern region but narrowed and covered a deeper cross-sectional area (Figure 4c). The Cresswell current was present as an easterly flow along the shallow continental shelf with current speeds similar to the Capes current along the west coast. Both undercurrents (FC and LU) were of similar magnitude. 

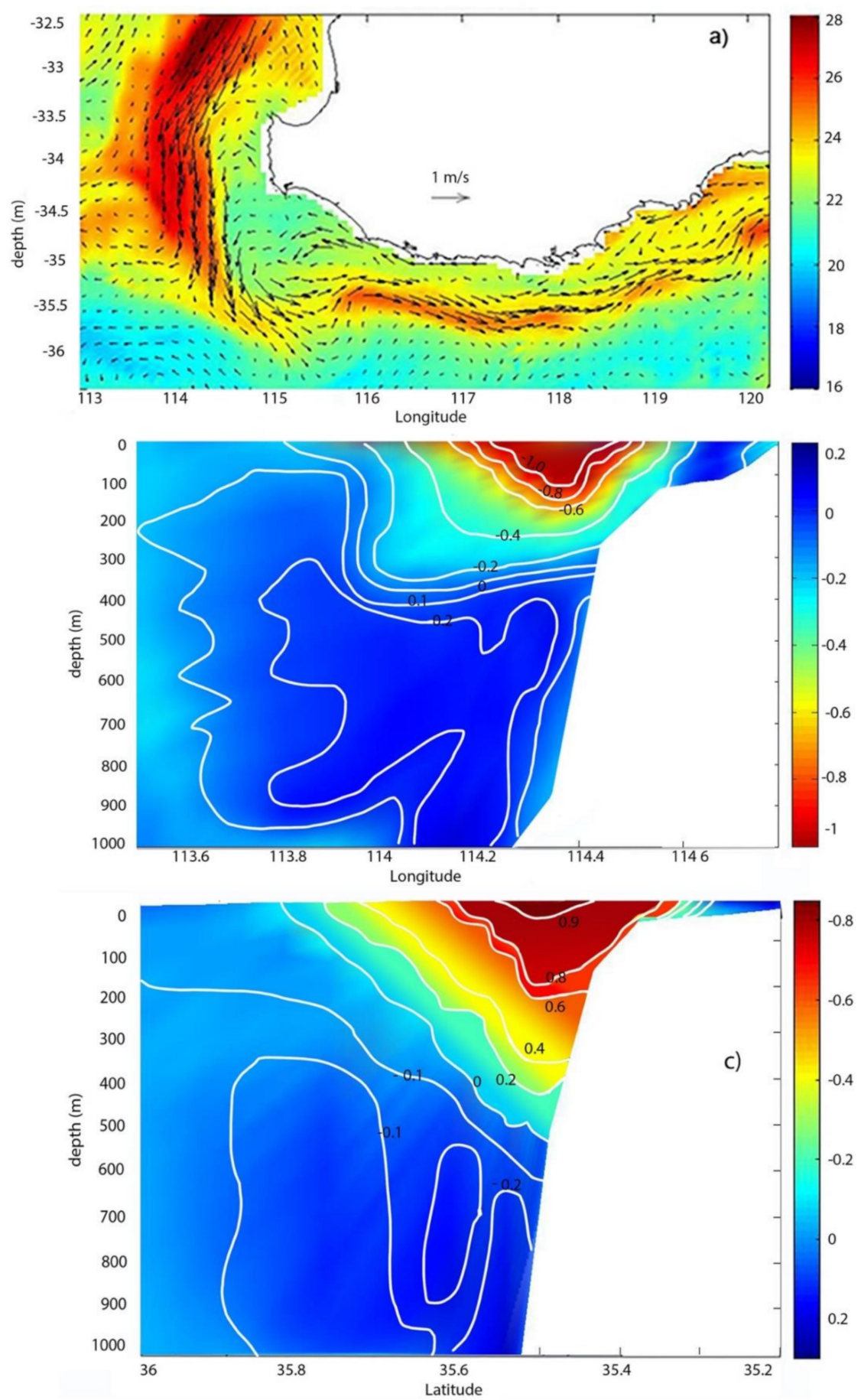

Figure 4. Model output with wind stress forcing representing summer conditions. (a) Sea surface temperature $\left({ }^{\circ} \mathrm{C}\right.$ ) and current velocities; (b) the cross-section across transect $\mathrm{R}$ (Capes region) showing the north-south velocity (m/s); (c) the cross-section across transect K (Albany) showing the east-west velocity $\left(\mathrm{ms}^{-1}\right)$.

\subsubsection{Autumn}

The LC was stronger during autumn compared to summer. The surface current was strongest after it had passed Cape Leeuwin (at $\sim 116^{\circ}$ E, Figure 1a) and on a path to the south of Albany (Figure 5a). The current reached speeds of more than $1.1 \mathrm{~m} / \mathrm{s}$, but weakened as it flowed eastward. The same feature was described by Cresswell and Domingues [8]. Along the west coast, the warmer LC waters flowed onto the shelf, although there was a weak Capes current on the inner shelf (Figure 5b). Some upwelling 
was still present near the Capes region and farther north, but it covered less shelf area than it had in summer. Along the south coast, the FC flowed eastward, offshore of the LC, with speeds of $\sim 0.2 \mathrm{~m} / \mathrm{s}$ and a temperature of $\sim 17^{\circ} \mathrm{C}$, similar to the model simulations by Middleton and Cirano [10].
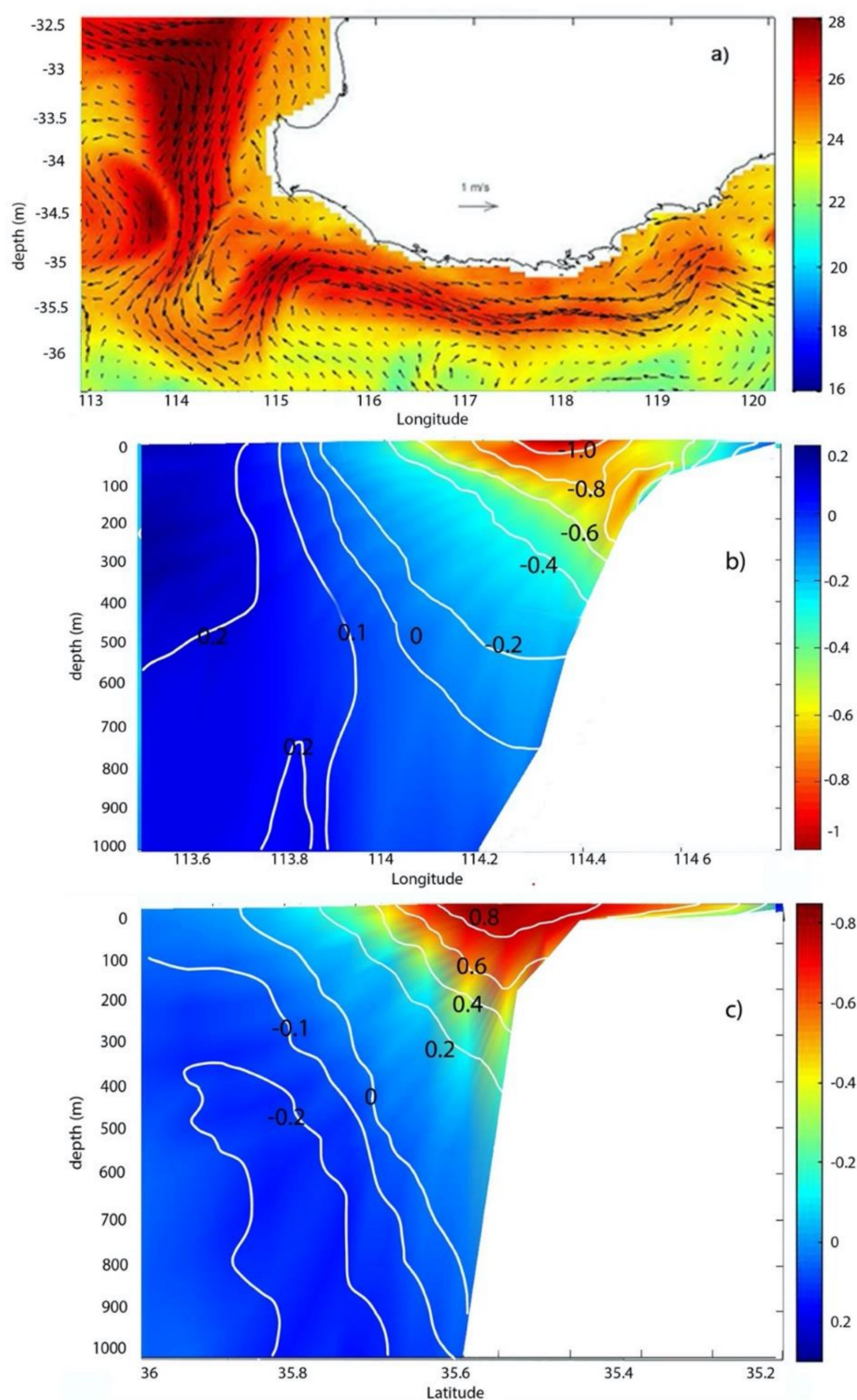

Figure 5. Model output with wind stress forcing representing autumn conditions. (a) Sea surface temperature $\left({ }^{\circ} \mathrm{C}\right)$ and current velocities; (b) the cross-section across transect $\mathrm{R}$ (Capes region) showing the north-south velocity $(\mathrm{m} / \mathrm{s})$; (c) the cross-section across transect $\mathrm{K}$ (Albany) showing the east-west velocity $\left(\mathrm{ms}^{-1}\right)$.

Transect R showed the LC had increased to $400 \mathrm{~m}$ depth and covered more area on the shelf (Figure 5b). At Transect K, the LC covered nearly the whole shelf, with its core above the shelf break (Figure 5c). The LC depth had increased to $500 \mathrm{~m}$, and the core of the FC core was located offshore of the continental slope. 


\subsubsection{Winter}

On average, sea surface temperature in winter was lower compared with both summer and autumn. The warmer LC core was present on the shelf, with the surface temperature $\sim 2{ }^{\circ} \mathrm{C}$ less than in autumn (Figure 6a). The current flowed closer to the coast and with the strongest currents $(\sim 1.0 \mathrm{~m} / \mathrm{s})$ off the south-west corner.
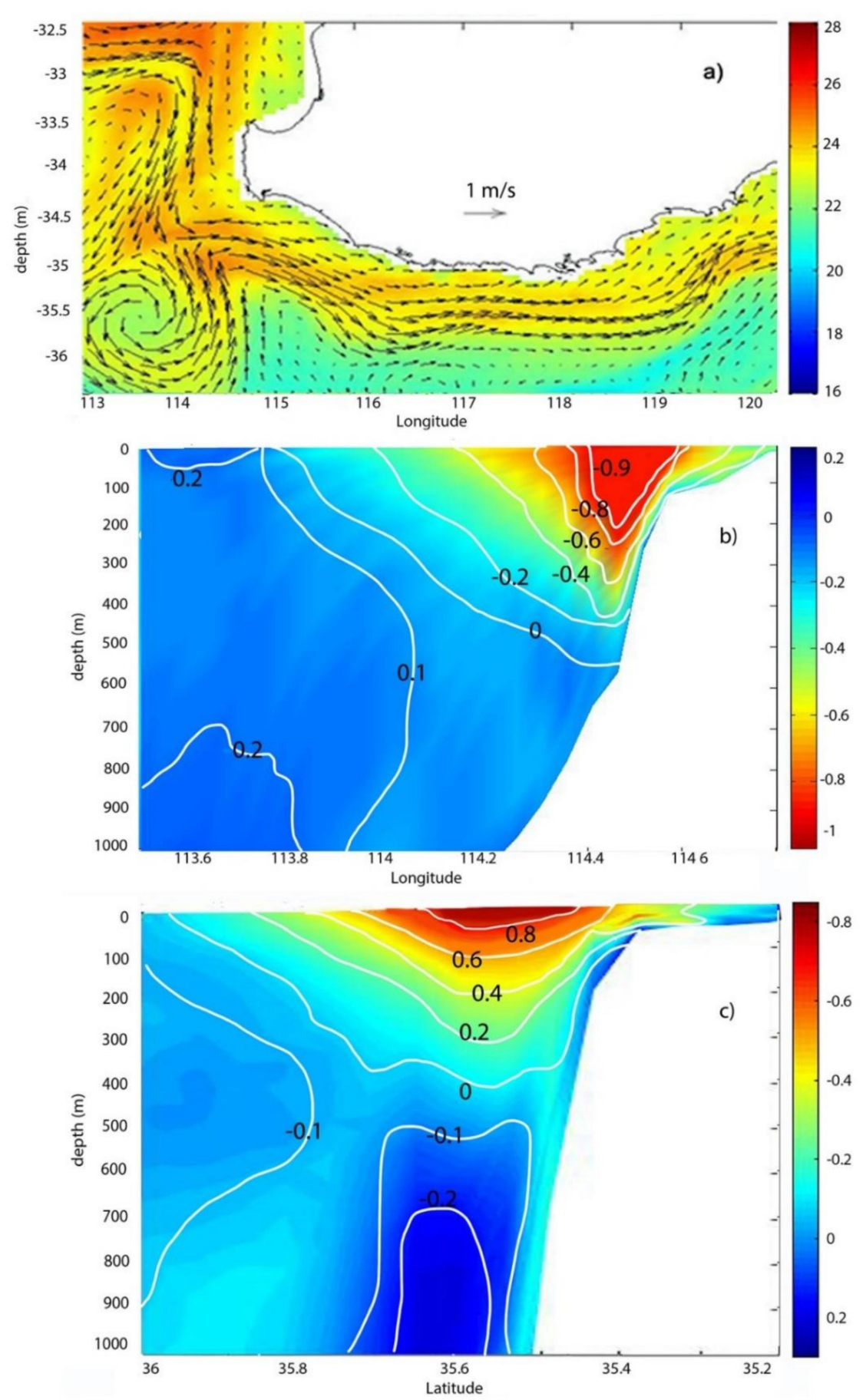

Figure 6. Model output with wind stress forcing representing winter conditions. (a) Sea surface temperature $\left({ }^{\circ} \mathrm{C}\right.$ ) and current velocities; (b) the cross-section across transect $\mathrm{R}$ (Capes region) showing the north-south velocity $(\mathrm{m} / \mathrm{s})$; (c) the cross-section across transect $\mathrm{K}$ (Albany) showing the east-west velocity $\left(\mathrm{ms}^{-1}\right)$. 
Transect $\mathrm{R}$ showed the LC, with its core near the slope, covering almost the whole shelf (Figure $5 b$ ). The LC depth extended to $500 \mathrm{~m}$, and the core of the current was narrower; the eddy offshore the transect (Figure 6a) likely caused this narrowing. Transect K showed the LC had strengthened and covered a larger cross-section than it had in autumn. The LC core was slightly offshore because of the wider area that the LC covered (Figure $6 \mathrm{c}$ ). The LC depth was $\sim 300 \mathrm{~m}$, and the FC, which was centered below the LC core, flowed westward with a maximum speed of $\sim 0.3 \mathrm{~m} / \mathrm{s}$. The coastal current, however, had disappeared, as in winter the winds had changed from predominantly having an easterly component to a westerly component.

The LC at Transect $\mathrm{K}$ in winter was wider, accompanied by a slightly stronger undercurrent. This was similar to what found by Batteen and Miller [26]. Earlier model shows undercurrent along the west coast can be generated due to meridional variability [27] and/or to the planetary beta effect (e.g., [28]). The beta effect allows the existence of freely propagating planetary waves, i.e., Rossby waves [14]. The offshore propagation of these waves contributes to the generation of an alongshore pressure gradient field, which can aid the development of subsurface currents along the eastern boundary. In time, the surface current can widen, causing the undercurrent to intensify and extend closer to the surface. As a result, the beta effect can change both the vertical and horizontal structure of the surface and subsurface currents [26].

\subsection{The Influence of Wind Stress}

A model run was undertaken without prescribing wind stress to determine its importance as a forcing mechanism of the currents along the south coast. The summer and winter conditions were compared because along the south coast, the winds reverse in direction between these two seasons: in summer, the winds have a dominant easterly component, whereas in winter the winds have a strong westerly component.

The model simulations without wind stress indicated a strong Leeuwin current, with the southerly flows extending onto the shelf along both west and south coasts. The cross-sectional transects $\mathrm{R}$ and $\mathrm{K}$ were similar to the model runs with wind stress forcing (Figure $6 \mathrm{~b}, \mathrm{c}$ ). At transect $\mathrm{R}$, the LC was centered on the shelf break, extending to $350 \mathrm{~m}$ depth, with maximum currents of $1.2 \mathrm{~m} / \mathrm{s}$ (Figure $7 \mathrm{~b}$ ). The almost identical velocity distribution between the model simulations with and without wind stress (Figures $6 \mathrm{~b}$ and $7 \mathrm{~b}$ ) indicated that the effects of wind stress were very little for the Leeuwin current dynamics during winter along the west coast. Along the south coast, transect K showed that the LC extended farther offshore, with a weakening of the FC at the surface, although the FC beneath the LC reached speeds of $\sim 0.2 \mathrm{~m} / \mathrm{s}$ (Figure $7 \mathrm{c}$ ). In winter, the Leeuwin current was stronger (Figure $6 \mathrm{c}$ ) than that predicted in the absence of wind forcing. 

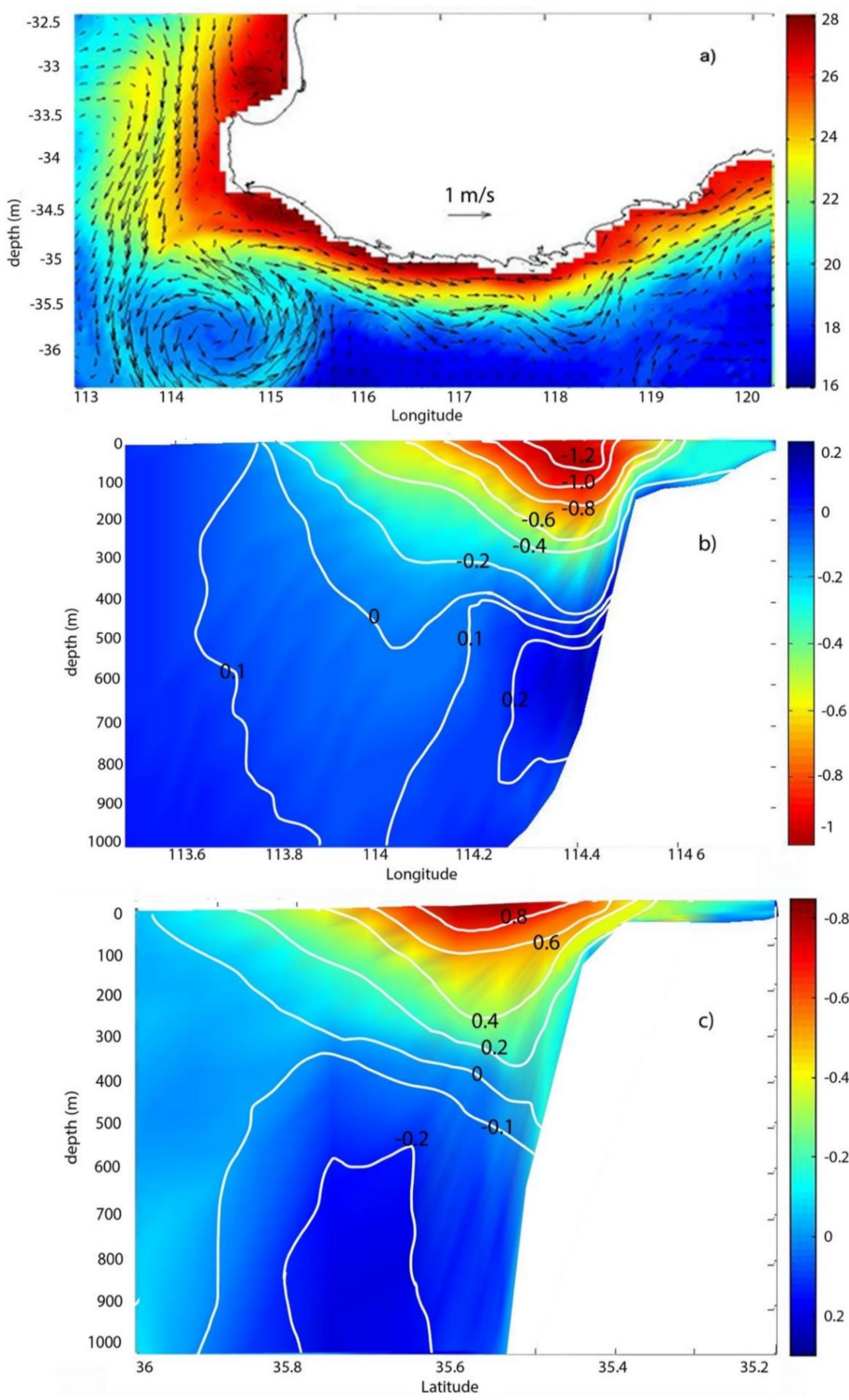

Figure 7. Model output with wind stress forcing representing winter conditions but without wind forcing. (a) Sea surface temperature $\left({ }^{\circ} \mathrm{C}\right)$ and current velocities; (b) the cross-section across transect $\mathrm{R}$ (Capes region) showing the north-south velocity $(\mathrm{m} / \mathrm{s})$; (c) the cross-section across transect $\mathrm{K}$ (Albany) showing the east-west velocity $\left(\mathrm{ms}^{-1}\right)$.

\section{Discussion}

\subsection{The Leeuwin Current}

Field and numerical modelling studies showed the LC flows southward along the west Australian coast, and after flowing past the southwest corner of Australia, it flows eastward. Although the model simulations presented here have broadly reproduced the observations and results of previous 
investigators, the discussion on LC will be focus in elaborating the current system dynamics that modulate through seasons. In this particular system there are two important dynamics involved: geopotential gradient and wind stress.

One of the distinctive features along the LC flow is the acceleration along the southwest corner. Field data collected near the area during 2006 indicated that the LC accelerated along the southwest corner in a response to an increase of geopotential gradient [5,12]. Griffiths and Pearce [14], using high-resolution infrared images from NOAA-7, found that the maximum currents $(\sim 1.8 \mathrm{~m} / \mathrm{s})$ along Australia's south coast occurred near Cape Leeuwin. Subsequently, several numerical models have reproduced the same behavior that resulted in acceleration and strong currents in this region [28,29]. Recent studies by Wijeratne et al. [5] and Yit Sen Bull and Sebille [30] provided more details on the transport of LC by showing that, instead of moving offshore, it brings significant volume of water eastward into the southern coast of Western Australia. To illustrate this dynamical importance, the alongshore geopotential gradient was calculated using model results at the LC core from the surface to $300 \mathrm{~m}$ depth. The model reproduced this feature for all three seasons, and also reflected the increased (model-predicted) geopotential gradient in the region, with the maximum slope located off the southwest corner (Table 1). The results also indicated a slight variation in the geopotential gradient between the three seasons, with maxima in winter corresponding to the maximum flow and the minima in summer (Table 1), suggesting the role of the geopotential gradient as the driving force of the LC throughout the year. The sharp density changes (due to temperature/salinity) between the west and south coast's in the vicinity of Cape Leeuwin is most likely the result of the steeper geopotential slope at the southwest corner.

Table 1. Geopotential gradient for summer, autumn and winter at the location of the maximum Leeuwin current (LC) speeds and at the south-west corner. The geopotential anomaly was calculated between the surface and $300 \mathrm{~dB}$ along the LC core.

\begin{tabular}{ccc}
\hline Seasons & $\begin{array}{c}\text { Slope at Maximum } \\
\text { LC }\end{array}$ & Slope at SW Corner \\
\hline Summer & $0.881 \times 10^{-7}$ & $2.08 \times 10^{-7}$ \\
Autumn & $0.907 \times 10^{-7}$ & $1.90 \times 10^{-7}$ \\
Winter & $1.190 \times 10^{-7}$ & $2.10 \times 10^{-7}$ \\
\hline
\end{tabular}

The model results also indicated that the LC strength and the surface temperatures varied throughout the year. The highest temperatures were recorded in autumn (April-May), when the LC core reached the southern region [6,31]. Cresswell and Domingues [8] summarized the seasonal behavior of the LC along the south coast as follows: "From December to March, the boundary flow of the Leeuwin current is quiescent. It suddenly pulses in April and evolves into a vigorous current during austral winter. The eastward flow of the Leeuwin current in the Great Australian Bight is initially strongest only on the western part of the basin, but by July/August it has accelerated along the entire basin. The vigorous flow then becomes unstable and dissipates a large amount of its energy by shedding mesoscale eddies." The model simulations from this study not only reproduced this seasonal behavior of LC but was also able to elaborate the influence of seasonal wind stress in the dynamics of the system.

Different wind directions observed between the south and west coasts provided significant influence on LC dynamics through different seasons. Table 2 show the analysis of LC strength that presented in a form of transport $\left(10^{6} \mathrm{xms}^{-1}\right.$ or Sv), which is the function of speed and area covered by $\mathrm{LC}$ from the figure. Along the south coast (transect $\mathrm{K}$ ), the winds were mainly westerly in autumn and winter, i.e., in the same direction of the LC. This resulted in a stronger LC (Table 2), which was deeper and flowed closer to the shelf. In summer, the winds along the south coast were mainly easterly (i.e., against the current), which weakened the LC. Along the west coast (Transect R), the LC was much 
stronger during winter than it was in summer (Table 2). Both the FC and the LU were marginally stronger in summer compared to winter, as found by Middleton and Cirano [10].

Table 2. Volume transport of the Leeuwin current, Leeuwin undercurrent and Flinders current in summer and winter across transects $\mathrm{R}$ (Capes region) and $\mathrm{K}$ (Albany), with and without wind stress (units: Sverdrup).

\begin{tabular}{|c|c|c|c|c|c|}
\hline & & \multicolumn{2}{|c|}{ With Wind Stress } & \multicolumn{2}{|c|}{ Without Wind Stress } \\
\hline \multirow{3}{*}{ Transect K } & & LC & FC & LC & FC \\
\hline & Summer & 3.81 & 2.1 & 4.76 & 1.9 \\
\hline & Winter & 4.51 & 1.6 & 1.43 & 2.4 \\
\hline \multirow{3}{*}{ Transect $\mathrm{R}$} & & LC & LU & LC & LU \\
\hline & Summer & 2.08 & 2.75 & 2.87 & 2.5 \\
\hline & Winter & 5.61 & 2.2 & 5.04 & 2.8 \\
\hline
\end{tabular}

Note: Flinders current transport given for the undercurrent only.

There were few differences between the model runs without wind stress and the models runs with wind stress along the west coast. In summer, the LC was slightly stronger in the models runs without wind stress due to the removal of the southerly wind stress, while the LU was slightly weaker (Table 2). In winter, the pattern was reversed, with a slightly weaker LC and a slightly stronger LU in the absence of wind stress (Table 2).

The biggest difference between the wind and no wind model runs was found along the south coast, where the influence of westerly winds as a driving force of the LC was highlighted. The predicted transport of the LC (Table 2) was much higher with the inclusion of wind stress (4.5 Sv) than it was in the absence of wind stress $(1.4 \mathrm{~Sv})$. This was also reflected in the cross-sectional transect plots, which indicated a stronger and wider LC along the south coast with the inclusion of wind (Figures $6 \mathrm{c}$ and $7 \mathrm{c}$ ). Wijeratne et al. [5] also estimated the winter transport of the LC along the south coast to be $4.7 \mathrm{~Sv}$.

Both alongshore geopotential gradient and wind stress were identified as driving forces of the LC. Although the model results indicated the geopotential gradient forced the LC throughout the year and caused acceleration near the southwest corner, wind stress remained the main factor that controlling volume transport, speed and coverage of the LC during winter.

\subsection{The Leeuwin Undercurrent and the Flinders Current}

Along the southern coast, the simulations revealed the FC as the dominant flow extending from the surface to $>1000 \mathrm{~m}$ flowing westward from Tasmania and past Cape Leeuwin into the Indian Ocean [5] and this was reproduced in the results of this study. Along the continental slope, the FC appears as an undercurrent beneath the eastward flowing LC and a surface current further offshore (Figures 3-5). Field measurements using shipborne ADCP also confirmed that FC was both a surface and an undercurrent [4].

Seasonal variability of the LU revealed that the transport was higher during summer, followed by autumn, and weakest during summer. This is the opposite cycle to that of the LC and indicates that a stronger LC could be responsible for deepening of the LU and the transport to decrease during winter. The FC transport in summer and autumn resembled the LU transport for the same seasons. In winter, the surface flow of the FC, offshore of the LC, was weak, with the maximum currents consistently found under the LC. Middleton and Cirano [10] proposed that the stronger wind stress increased the FC transport during the summer months. The results from the model run without wind stress forcing agreed with this finding. In fact, the model output indicated that during summer, the presence of the surface FC offshore was weaker, with higher currents associated with the FC beneath the LC. In contrast, during winter, as the surface currents weakened, the FC covered a larger surface area.

The FC transport $\sim 2 \mathrm{~Sv}$ (Table 2), higher in summer, represented the undercurrent and was significantly smaller than the $8-17 \mathrm{~Sv}$ range usually associated with the FC. The model runs without 
wind stress also indicated the undercurrents (FC and LU) were stronger in winter than in summer. Hence, it appears that the undercurrent transport increased when the LC was weaker, and this usually happens in summer when the wind stress has less influence. From a different perspective, Woo and Pattiaratchi [2], through analysis of water masses along the west coast, indicated that under El Niño conditions, the depth range occupied by the sub Antarctic mode water (SAMW), the water mass associated with the LU was larger, indicating a higher transport of LU. The interannual variability of the LC is such that it is weaker during El Niño events [32,33]. This adds more credence to the suggestion that when the LC is weaker (stronger), the undercurrents were stronger (weaker).

The velocity field at $550 \mathrm{~m}$ depth showed a continuous FC undercurrent flowing on the continental slope along the south coast (Figure 8). At Cape Leeuwin, it appeared to bifurcate, with one arm flowing northwards as the LU and the other flowing westward into the Indian Ocean. This similar to the model results reported by Wijeratne et al. [5]. At the eastern section of the model domain, the FC was not well defined at this depth. The speed of the FC $\left(\sim 0.50 \mathrm{~ms}^{-1}\right)$ was greater along the continental slope at the subsurface of LC.

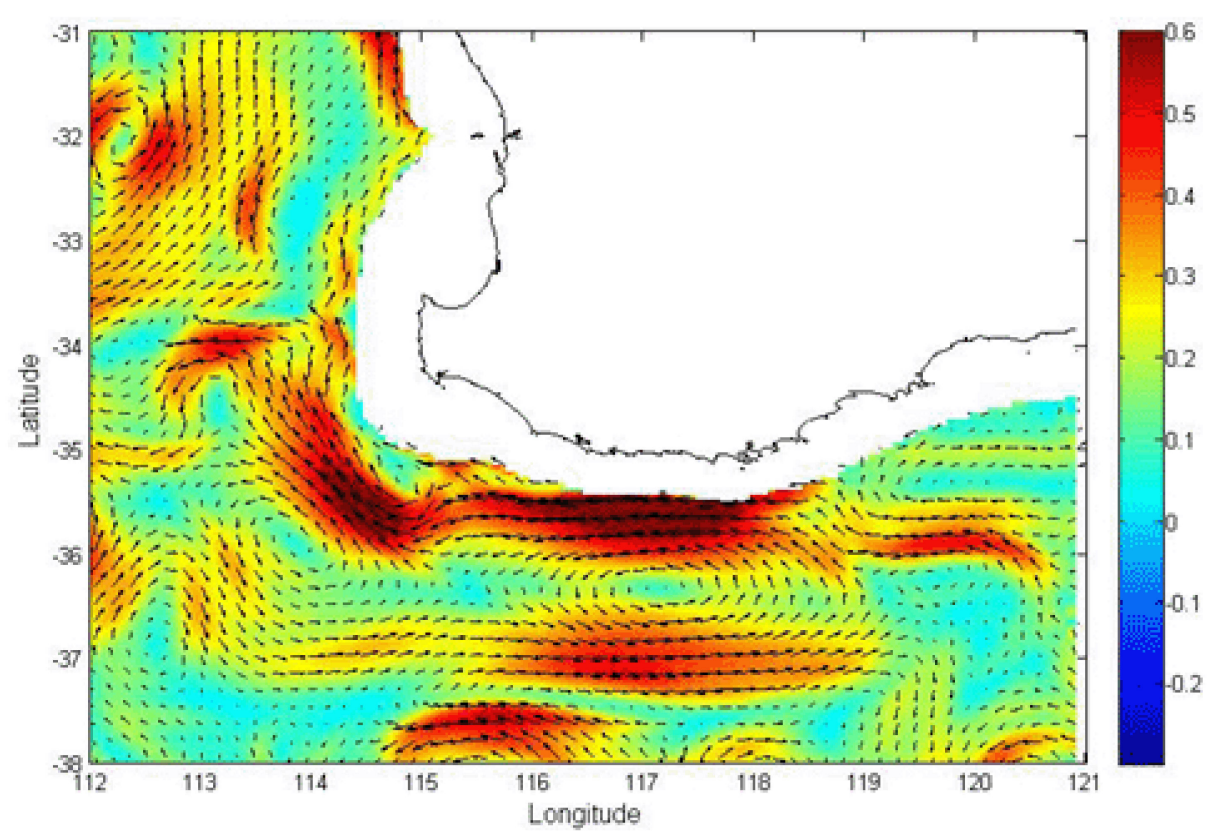

Figure 8. The velocity field at a depth of $550 \mathrm{~m}$ for the autumn. The colour bar indicates the velocity in $\mathrm{ms}^{-1}$.

\subsection{The Capes and Cresswell Currents}

The numerical simulations predicted the presence of both the Capes and Cresswell currents in summer and autumn, but not in winter. Summer sea surface temperature and velocity on the shelf off the Capes region and Albany reflected these two current systems (Figure 9). The cooler Cresswell current, flowing from east to west on the shelf with speeds of $\sim 0.2-0.3 \mathrm{~m} / \mathrm{s}$, was clearly present off Albany (Figure 9b), with the eastward flowing Leeuwin current further offshore. At Cape Leeuwin, the current fed the Capes current, as postulated by Gersbach et al. [14]. Transects $\mathrm{R}$ (Capes region) and K (Albany) showed the Cresswell current was confined to the upper terrace $(<70 \mathrm{~m})$; however, the Capes current extended further offshore into deeper water of up to $150 \mathrm{~m}$ depth (Figure 9c,d). The Cresswell current was generally stronger than the Capes current, especially between Albany and Point D'Entrecasteaux, most likely due to changes in the bathymetry: the shelf width and slope increase abruptly to the west of Point D'Entrecasteaux. Thompson [34] suggested that the balance between the 
alongshore geopotential gradient, wind stress and bottom friction in the alongshore direction may be expressed as:

$$
\int_{-H}^{0} \frac{1}{\rho}\left(\frac{\partial P}{\partial y}\right) d z+u_{*}^{2}+C_{D}\left|V_{B}\right| V_{b}=0
$$
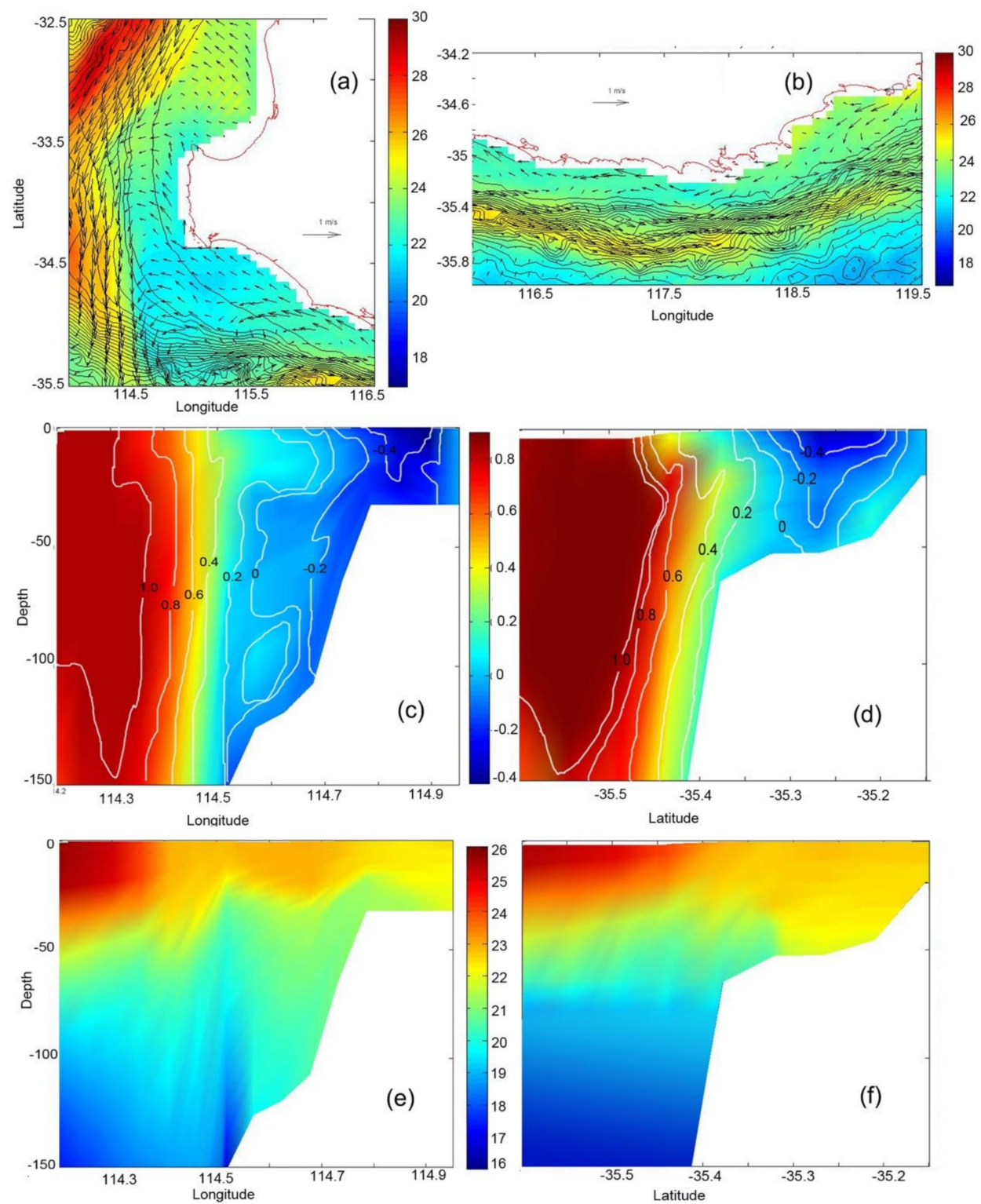

Figure 9. (a) Sea surface temperature $\left({ }^{\circ} \mathrm{C}\right)$ and Capes current velocity for the Capes region in summer. (b) Sea surface temperature $\left({ }^{\circ} \mathrm{C}\right)$ and Cresswell current velocity for the Albany region in summer. (c) Transect $R$ cross-section of the Capes current north-south velocity $(\mathrm{m} / \mathrm{s})$ in summer. (d) Transect K cross-section of the Cresswell current north-south velocity $(\mathrm{m} / \mathrm{s})$ in summer. (e) The Capes current summer temperature $\left({ }^{\circ} \mathrm{C}\right)$ at transect $\mathrm{R}$ (Capes region). (f) The Cresswell current summer temperature $\left({ }^{\circ} \mathrm{C}\right)$ at transect $\mathrm{K}$ (Albany). The color bars indicate the current velocity in $\mathrm{ms}^{-1}$.

Here, $\mathrm{z}$ is the vertical coordinate; $\mathrm{y}$ is the alongshore direction; $\mathrm{H}$ the local water depth; $\partial P / \partial y$ is the alongshore geopotential gradient; $\rho$ is mean density; $\mathrm{u} *$ is the friction velocity at the air-sea interface; $C_{D}$ is the bottom drag coefficient; and $V_{B}$ is the alongshore velocity just above the bottom friction layer. In the Equation (1), term 1 represents the depth-integrated alongshore geopotential 
gradient; term 2 represents the wind stress; and term 3 represents the bottom friction approximated using a quadratic law. Examining the balance of different terms in Equation (1) reveals that in shallow water, the depth-integrated geopotential gradient is small compared to wind and bottom stress terms. These results in the depth mean flow in the direction of the wind. However, as the water depth increases, the geopotential gradient becomes more important until a point is reached where the geopotential gradient balances the equatorward wind stress, resulting in zero depth-averaged velocity. Thompson [34] defined this depth as $\mathrm{H}^{*}$, given by:

$$
H^{*}=u_{*}^{2}\left(\frac{1}{\rho} \frac{\partial P}{\partial y}\right)^{-1}
$$

Thompson [34] postulated that upwelling would occur if $\mathrm{H}^{*}$ exceeded the mixed layer depth, and Gersbach et al. [14] showed that upwelling occurred off south-west Australia up to water depths of $70 \mathrm{~m}$. Along the south coast, as the shelf is narrower and the depth beyond the shelf break increases rapidly, the dominance of the wind over the alongshore pressure gradient is limited to the upper terrace at around $70 \mathrm{~m}$ (Figure 9d). The temperature difference between the Cresswell current at the shelf and the slope was about $2{ }^{\circ} \mathrm{C}$ and that indicates upwelling occurrence from beneath the LC (Figure 9e,f).

During autumn, the Cresswell current was present between Point D'Entrecasteaux and Cape Leeuwin and feeding the Capes current but was present only close to the coast near Albany (Figure 10a,b). Transect $R$ showed the Capes current reached speeds of $\sim 0.2 \mathrm{~m} / \mathrm{s}$ and was on the shelf (Figure 10c). The Cresswell current was only present close to the coast at Transect K (Figure 10d), with the eastward flowing LC spreading onto the continental shelf.
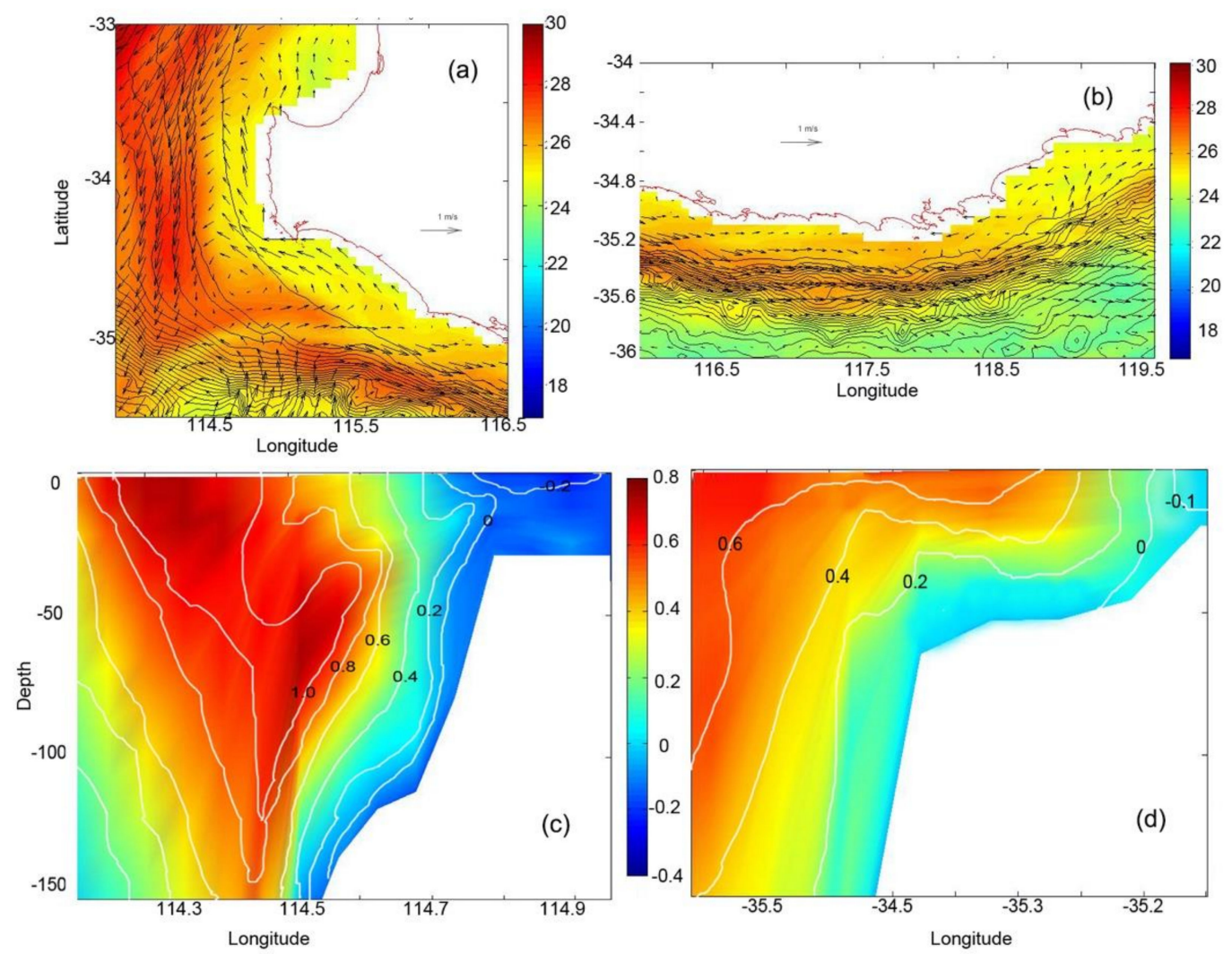

Figure 10. (a) Sea surface temperature $\left({ }^{\circ} \mathrm{C}\right)$ and Capes current velocity for the Capes region in autumn. (b) Sea surface temperature $\left({ }^{\circ} \mathrm{C}\right)$ and Cresswell current velocity for the Albany region in autumn.

(c) Transect R (Capes region) cross-section of the Capes current north-south velocity $(\mathrm{m} / \mathrm{s})$ in autumn.

(d) Transect K (Albany) cross-section of the Cresswell current north-south velocity ( $\mathrm{m} / \mathrm{s}$ ) in autumn. The color bars indicate the velocity in $\mathrm{m} / \mathrm{s}$. 
The Cresswell current was strong in summer when the winds were usually southeasterly. The wind direction in summer was upwelling-favorable for the Cresswell current and the Capes current; however, in autumn, the wind direction changed by $\sim 90^{\circ}$ (clockwise), resulting in onshore winds off Albany and southerly wind (upwelling-favorable) for the Capes current along the west coast. The wind stress was also weaker in autumn. The changes in wind stress, the driving force of the shelf current systems, explain why the Capes current was still present in autumn and the Cresswell current was weaker. Data obtained aboard the Southern Surveyor in autumn (Figure 3) also showed no evidence of the Cresswell current because of the dominance of southwesterly winds during the cruise. Similarly, the model simulations did not indicate the presence of the Cresswell or Capes currents during winter.

\section{Conclusions}

Model simulations reproduced the documented current patterns in the region and revealed the dynamics of the seasonal variability influenced by both alongshore geopotential gradient and wind. Wind stress in particular had a stronger influence in determining near coast current flow, while the strength of the major current system was determined by the forcing balance between the wind and geopotential gradient.

The current system along the south coast of Western Australia, which includes the LC, FC, and the Cresswell current, are schematically shown in Figure 11. Overall, the model results indicated that a warm LC flowed south past the southwest corner of Australia and accelerated as it moved east along the south coast. The current was present throughout the year, although its location on the shelf changed with the season. The alongshore geopotential gradient was the major driving force of the LC and was augmented by westerly wind stress during autumn and winter. During these seasons, the LC was deeper, flowed closer to the coast and transported $\sim 4.5 \mathrm{~Sv}$ of water to the east. The model runs without wind stress indicated less transport compared to the situation with the inclusion of wind.

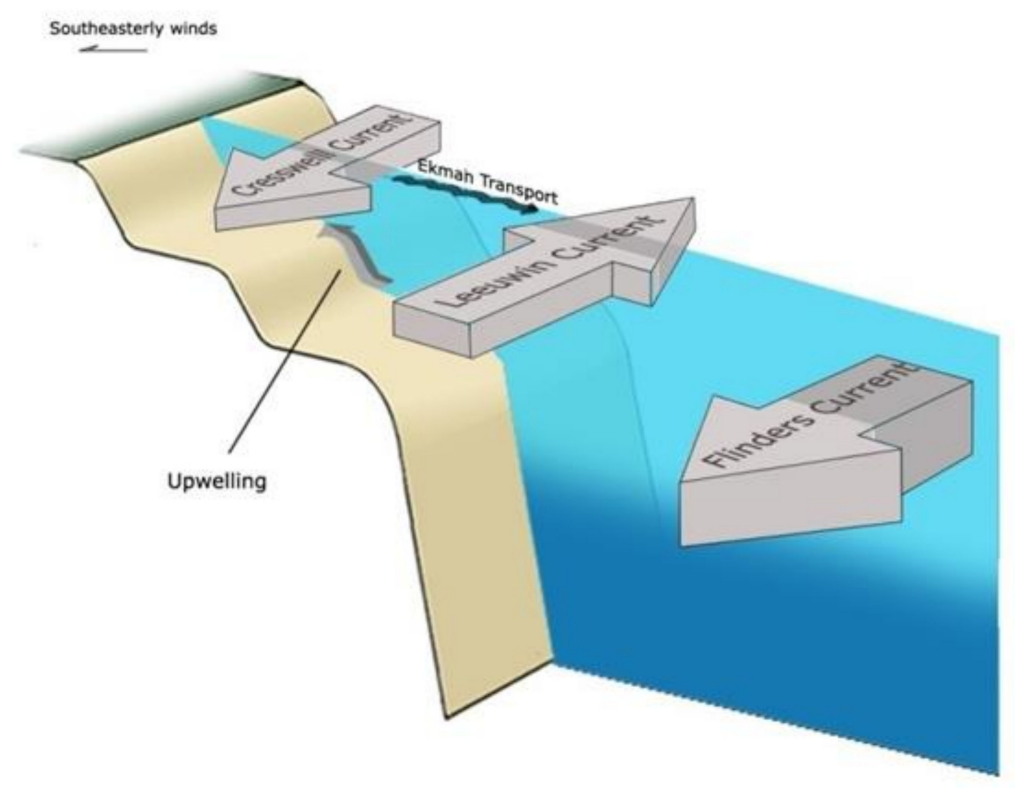

Figure 11. Schematic of the summer steady state current regime off Western Australia's south coast.

The westward flowing FC was present as both a surface current (offshore) and an undercurrent beneath the LC (at depths $>300 \mathrm{~m}$ ). Off Cape Leeuwin, the FC splits, with one arm feeding the LU while the other arm flowed into the Indian Ocean. The FC transport was higher in summer, and weaker in autumn and winter, when the LC was stronger. We found that the undercurrents were stronger (weaker) when the LC was weaker (stronger).

Closer to the coast, easterly winds were the driving force of the Cresswell current, which flowed to the west, inshore of the LC in summer and autumn. In summer, the current was strongest when the 
wind speeds were higher and were from the southeast. The current weakened in autumn when the winds speeds decreased and the winds became southwesterly. The Cresswell current was cooler than surrounding water because of upwelling and acted as a feeder current to the Capes current, which had similar dynamics.

Author Contributions: This study was done as a part of PhD research by M.F.A., All model data analysis and validation were done by M.F.A. with the supervision of C.P. The ROMS model output used for this study was generated by M.M. All authors have read and agreed to the published version of the manuscript.

Funding: This research was made possible by the postgraduate scholarship funded by the Ministry of Higher Education Malaysia and Universiti Malaysia Terengganu.

Acknowledgments: We would like to thank the Western Australia Interaction Virtual Environment Centre (IVEC) for access to the high-performance computer facility; BOM Australia and the team behind the BLUElink project; Scientists and crew onboard Southern Surveyor SS04/06; NOAA for providing MODIS SST data and Geoscience Australia for providing the bathymetry data.

Conflicts of Interest: The authors declare that the research was conducted in the absence of any commercial or financial relationships that could be construed as a potential conflict of interest.

\section{References}

1. Pattiaratchi, C.B.; Woo, L.M. The mean state of the Leeuwin current system between North West Cape and Cape Leeuwin. Proc. Roy. Soc. West. Aust. 2009, 92, 221-241.

2. Woo, M.; Pattiaratchi, C.B. Hydrography and waters masses off the Western Australian coast. Deep Sea Res. Part I Oceanogr. Res. Pap. 2008, 55, 1090-1104. [CrossRef]

3. Pattiaratchi, C.B. Surface and sub-surface circulation and water masses off Western Australia. Bull. Aust. Meteorol. Oceanogr. Soc. 2006, 19, 95.

4. Akhir, M.F. Physical processes along the southern continental shelf and slope of Western Australia. Ph.D. Thesis, University of Western Australia, Perth, Australia, 2010.

5. Wijeratne, S.; Pattiaratchi, C.; Proctor, R. Estimates of surface and subsurface boundary current transport around Australia. J. Geophys. Res. Ocean. 2018, 123, 3444-3466. [CrossRef]

6. Ridgway, K.R.; Condie, S.A. The $5500 \mathrm{~km}$ long boundary flow off western and southern Australia. J. Geophys. Res. 2004, 109, C04017. [CrossRef]

7. Cresswell, G.R.; Peterson, J.L. The Leeuwin Current South of Western Australia. Aust. J. Mar. Freshw. Res. 1993, 44, 285-303. [CrossRef]

8. Cresswell, G.R.; Domingues, C.M. The Leeuwin Current south of Western Australia. Proc. Roy. Soc. West. Aust. 2009, 92, 83. [CrossRef]

9. Middleton, J.F; Bye, J.A.T. A review of the shelf-slope circulation along Australia's southern shelves: Cape Leeuwin to Portland. Prog. Oceanogr. 2007, 75, 1-41. [CrossRef]

10. Middleton, J.F.; Cirano, M. A northern boundary current along Australia's southern shelves: The Flinders Current. J. Geophys. Res. 2002, 107, 3129. [CrossRef]

11. Woo, L.M.; Pattiaratchi, C.B.; Schroder, W. Summer surface circulation along the Gascoyne continental shelf, Western Australia. Cont. Shelf Res. 2006, 26, 132-152. [CrossRef]

12. Godfrey, J.S.; Vaudrey, D.J.; Hahn, S.D. Observations of the shelf-edge current south of Australia, winter 1982. J. Phys. Oceanogr. 1986, 16, 668-679. [CrossRef]

13. Menezes, V.V.; Phillips, H.E.; Vianna, M.L.; Bindoff, N.L. Interannual variability of the South Indian Countercurrent. J. Geophys. Res. Oceans 2016, 121, 3465-3487. [CrossRef]

14. Griffiths, R.W.; Pearce, A.F. Instability and eddy pairs on the Leeuwin current south of Australia. Deep Sea Research Part A. Oceanogr. Res. Pap. 1985, 32, 1511-1534. [CrossRef]

15. Batteen, M.L.; Kennedy, R.A., Jr; Miller, H.A. A process-oriented numerical study of currents, eddies and meanders in the Leeuwin Current System. Deep Sea. Res. Part II Top. Stud. Oceanogr. Leeuwin Curr. Its Eddies 2007, 54, 859-883. [CrossRef]

16. Pearce, A.; Pattiaratchi, C.B. The Capes Current: A summer countercurrent flowing past Cape Leeuwin and Cape Naturaliste, Western Australia. Cont. Shelf Res. 1999, 19, 401-420. [CrossRef]

17. Gersbach, G.H.; Pattiaratchi, C.B.; Ivey, G.N.; Cresswell, G.R. Upwelling on the south-west coast of Australia-Source of the Capes Current? Cont. Shelf Res. 1999, 19, 363-400. [CrossRef] 
18. Hazel, J.V. The climate and physical oceanography of the Recherche Archipelago and adjacent waters. Undergraduate Thesis, University of Western Australia, Perth, Australia, 2001.

19. Haidvogel, D.B.; Arango, H.G.; Hedstrom, K.; Beckmann, A.; Malanotte-Rizzoli, P.; Shchepetkin, A.F. Model evaluation experiments in the North Atlantic Basin: Simulations in nonlinear terrain-following coordinates. Dyn. Atmos. Ocean. 2000, 32, 239-281. [CrossRef]

20. Shchepetkin, A.F.; McWilliams, J.C. The regional oceanic modeling system (ROMS): A split-explicit, free-surface, topography-following-coordinate oceanic model. Ocean Model. 2005, 9, 347-404. [CrossRef]

21. Kantha, L.H.; Clayson, C.A. Numerical Models of Oceans and Oceanic Processes; Academic Press: Waltham, MA, USA, 2000.

22. Song, Y.T.; Wright, D.G. A general pressure gradient formulation for ocean model. Part II: Energy, momentum, and bottom torque consistency. Mon. Weather Rev. 1998, 126, 3231-3247. [CrossRef]

23. Mellor, G.L.; Yamada, T. Development of a turbulence closure model for geophysical fluid problems. Rev. Geophys. Space Phys. 1982, 20, 851-875. [CrossRef]

24. Meuleners, M.J.; Pattiaratchi, C.B.; Ivey, G.N. Numerical Modelling of the mean flow characteristics of the Leeuwin Current system. Deep Sea Res. Part II Top. Stud. Oceanogr. 2007, 54, 837-858. [CrossRef]

25. Oke, P.R.; Brassington, G.B.; Griffin, D.A.; Schiller, A. The Bluelink ocean data assimilation system (BODAS). Ocean Model. 2008, 21, 46-70. [CrossRef]

26. Batteen, M.L.; Miller, H.A. Process-oriented modelling studies of the $5500 \mathrm{~km}$ long boundary flow off western and southern Australia. Cont. Shelf Res. 2009, 29, 702-718. [CrossRef]

27. Batteen, M.L.; Rutherford, M.J. Modelling studies of eddies in the Leeuwin Current: The role of thermal forcing. J. Phys. Oceanogr. 1990, 20, 1484-1520. [CrossRef]

28. Batteen, M.L.; Butler, C.L. Modeling Studies of the Leeuwin Current off Western and Southern Australia. J. Phys. Oceanogr. 1998, 28, 2199-2221. [CrossRef]

29. Weaver, A.J.; Middleton, J.H. On the dynamics of the Leeuwin Current. J. Phys. Oceanogr. 1989, 19, 626-648. [CrossRef]

30. Yit Sen Bull, C.; van Sebille, E. Sources, fate, and pathways of Leeuwin Current water in the Indian Ocean and Great Australian Bight: A Lagrangian study in an eddy-resolving ocean model. J. Geophys. Res. Ocean 2016, 121, 1626-1639. [CrossRef]

31. Ridgway, K.R.; Godfrey, J.S. The source of the Leeuwin Current seasonality. J. Geophys. Res. Ocean. 2015, 120, 6843-6864. [CrossRef]

32. Rennie, S.J.; Pattiaratchi, C.B.; McCauley, R.D. Eddy formation through the interaction between the Leeuwin current, Leeuwin undercurrent and topography. Deep Sea Res. Part II Top. Stud. Oceanogr. 2007, 54, 818-836. [CrossRef]

33. Hanson, C.E.; Pattiaratchi, C.B.; Waite, A.M. Seasonal production regimes off south-western Australia: Influence of the Capes and Leeuwin Currents on phytoplankton dynamics. Mar. Freshw. Res. 2005, 56, 1011-1026. [CrossRef]

34. Thompson, R.O.R.Y. Continental Shelf scale model of Leeuwin Current. J. Mar. Res. 1987, 45, 813-827. [CrossRef]

(C) 2020 by the authors. Licensee MDPI, Basel, Switzerland. This article is an open access article distributed under the terms and conditions of the Creative Commons Attribution (CC BY) license (http://creativecommons.org/licenses/by/4.0/). 